\title{
Interaction of gold nanoparticles with cholesterol oxidase enzyme in bionanocomplex - determination of the protein structure by Fourier transform infrared spectroscopy
}

\author{
Renata Wojnarowska-Nowak (D) • Jacek \\ Polit (D) Eugen M. Sheregii (i)
}

Received: 1 August 2019 / Accepted: 22 April 2020 / Published online: 5 May 2020

(C) The Author(s) 2020

\begin{abstract}
The bionanocomplexes of proteins and nanoparticles are promising bionanomaterials for medical purposes like the sensitive and the selective diagnostic devices, as well as, the modern therapeutic agents. The presence of the noble metals allows for obtaining the plasmonic effect and for generating the surfaceenhanced Raman scattering phenomenon (SERS). The knowledge of the nanoparticle interaction with the protein molecule is extremely necessary for the development of the suitable product. The interaction of the bionanocomplex components can cause the conformational changes in the protein structure and the modification of surface properties of the nanoparticles. In the case of the binding of the gold nanoparticles with the enzymes, it is critical to preserve the catalytic activity, which is connected with maintaining the proper molecule structure. In the presented study, the Fourier transform infrared spectroscopy was used for the investigation of the interaction and the structural properties of the cholesterol oxidase (ChOX) - the gold nanoparticles bionanocomplex. The ChOX is one of the most important enzymes for the medical diagnostics and the promising antibacterial agent. The infrared spectra of the AuNP-ChOX bionanocomplex and the ChOX in different forms (the solid and the suspended in the buffer) are presented and discussed. The obtained spectra include the considerable number of the absorption lines
\end{abstract}

R. Wojnarowska-Nowak $(\bowtie) \cdot$ J. Polit $\cdot$ E. M. Sheregii Centre for Microelectronics and Nanotechnology, Institute of Physics, University of Rzeszow, Pigonia 1 Str., 35-310 Rzeszow, Poland

e-mail: rwojnar@ur.edu.pl identified and attributed to the corresponding chemical bonds and the functional groups of the protein. The analysis of the obtained infrared spectra revealed the important information about the changes of the protein structure after the immobilization on the gold nanoparticles. Moreover, it allows to recognize the differences in the structure of the protein in a different environment, which is of great importance in the context of bionanotechnology.

Keywords Cholesterol oxidase - Gold nanoparticle · Bionanocomplexes · FTIR spectroscopy Protein secondary structure

\section{Introduction}

Cardiovascular diseases are the most common causes of disability and mortality (32\% of the deaths in the Global Burden of the Disease Study report). The risk related to the burden of the disease and the health effects is associated with many risk factors, among which, the high cholesterol level is estimated as the most significant, causing numerous deaths (about 4.4 million of deaths annually) (Global Burden of Disease Collaborative Network 2016). Therefore, it is very important to carefully monitor the cholesterol level in the blood. The cholesterol is a biomarker of the coronary heart disease, the arteriosclerosis, and the lipid metabolism dysfunction and determining the risk of the heart attack (MacLachlan et al. 2000; Vrielink and Ghisla 2009). To determine the serum cholesterol content, the 
cholesterol oxidase enzyme (EC 1.1.3.6; ChOX) is widely employed. For this reason, it is one of the most important enzymes in the clinical analysis. Besides the diagnostic application, the ChOX is an important industrial enzyme. It is used in the bioconversions, the cholesterol transformation, and the biocatalytic processes of pharmaceutical steroid production. It is also a novel antibacterial/antifungal agent (Wang and Wang 2007; Vrielink 2010; Kumari, and Kanwar 2012). The great attention in ChOX is also influenced by the possibility of using it as an anticancer factor in modern cancer therapies (El-Naggar et al. 2018).

The ChOX is a bifunctional enzyme, belonging to the family of the oxidoreductases, which catalyzes the oxidation of the cholesterol as well as the isomerization of the intermediate substance (the cholest-5-en-3-one) in order to produce the cholest-4-en-3-one (Vrielink 2010; Kumari, and Kanwar 2012). This bacterial-specific enzyme was isolated for the first time from the Rhodococcus erythropolis (Kumari, and Kanwar 2012), but it is also produced by the other microorganisms: the Streptomyces hygroscopicus, the Brevibacterium sterolicum (Gadda et al. 1997), the Brevibacterium sp. (Lv et al. 2002), the Streptomyces sp., the Nocardia sp., and the Pseudomonas sp. for example (MacLachlan et al. 2000). The ChOX is a flavin adenine dinucleotide (FAD)-dependent enzyme (MacLachlan et al. 2000; Vrielink 2010; Kumari, and Kanwar 2012). The FAD is the nonproteinaceous part of enzyme, and it is deeply seated in a protein core. The presence of the FAD molecule is necessary for the catalytic activity of the enzyme (MacLachlan et al. 2000).

The development of the rapid and the accurate diagnostic methods such as the contemporary and the sensitive biosensors for the cholesterol is still an ongoing process (Pollegioni et al. 2009, Neelama et al. 2019). The biosensor is an analytical device that combines a biological component with a physicochemical detector, giving the information about the presence of a molecule. Therefore, the extensive researches on constructing the modern electrochemical as well as the optical biosensors for the cholesterol are carried out. For this purpose, the bionanocomplexes of the ChOX and the noble metal nanoparticles (MNPs) are prepared. The two main ways of AuNPs-ChOX systems creation are described: AuNPs with ChOX adsorbed on AuNPs and AuNPs with ChOX covalently attached on AuNPs. In addition to the connection method, many other factors affect the properties of the complex, e.g. size of the nanoparticles, their shape, and concentration of the attached molecule (Saxena and Goswami 2012). In the context of developing new biosensors for the cholesterol detection, combining the ChOX with other nanostructures, e.g. MWCNTs, is also an interesting approach (Saxena et al. 2011b). The published works also show the possibility of effective use of more natural substrates (like the silk mat) for the ChOX immobilization with high stability, sensitivity, reproducibility, and good selectivity for cholesterol (Saxena and Goswami 2010).

The MNPs have an excellent conductivity; they enhance the transfer of the electrons generated during the chemical reactions catalyzed by the enzymes (Saxena et al. 2011a). The binding of the MNPs with the enzyme is applied in the construction of the sensitive electrochemical biosensors (Sharma et al. 2017). In addition to the electrochemical sensors, a new optical biosensors based on the use of the ChOX enzyme connected with the nanomaterials is developed. Through the surface plasmon resonance (SPR) phenomenon (Barnes et al. 2003), obtained due to the plasmonic nanomaterials, the surface-enhanced Raman scattering (SERS) effect extends the possibilities of the vibrational spectroscopy (Nie and Emory 1997; Stuart et al. 2006; Wojnarowska et al. 2015a) and enables the creation of the sensitive SPR and the SERS optical biosensors (Haes and Van Duyne 2002; Zhang et al. 2013). The SERS technique is a powerful analytical tool, which is employed as one of the approaches in the construction of the new diagnostic equipment, allowing to study even the single molecules. In contrast to this approach, the simple colorimetric sensors for the quick cholesterol detection are also constructed (Nirala et al. 2018). The published papers demonstrate also the benefits of combining the ChOX with the MNP including the AuNP as well as the other nanomaterials such as the $\mathrm{CdTe} / \mathrm{CdSe} /$ $\mathrm{ZnSe} / \mathrm{MoS}_{2}$ quantum dots, the grapheme, the graphene oxide, and MWCNTs (Saxena et al. 2011a, b; Hassanzadeh and Khataee 2018; Mokwebo et al. 2018).

It was observed that the engineered bionanocomplexes give the great opportunity for the development of the new analytical, diagnostic, and the therapeutic methods, by combining the unique properties of the nanomaterials with the biological functionality of the biological molecules. Moreover, the conjugation of the gold nanoparticles (the AuNP) with the proteins gives a better biocompatibility and improves the stabilization of the system (Rios-Corripio et al. 2013; Alarcon et al. 2013). The 
interaction of the nanoparticles with the protein molecules, which results in the formation of a biological corona on the nanoparticle surface, can also affect the modification of the nanomaterial properties as well as the changes in the protein structure (Kumar et al. 2018). In the case of the immobilization of the gold nanoparticles with the enzymes molecules, it is critical to preserve the basic properties of the enzyme, which is the catalytic activity.

In the presented paper, the Fourier transform infrared spectroscopy (FTIR) was used as the versatile tool to study the protein conformation (including the secondary structure) of the ChOX enzyme immobilized on the surface of AuNP via linker. By the use of the infrared spectroscopy, a unique spectrum is obtained, which is a representative of the molecular vibrations that occur within the sample. It provides a "fingerprint" of the sample. This method is suitable for the biological materials, including the proteins and the enzymes (Baker et al. 2014). It provides an important information about the structure of the molecules, their interactions, the mechanisms of protein reactions, and the conformational changes (Barth 2007; Dembereldorja et al. 2012). The structure of the ChOX conjugated with the AuNPs was compared with the ChOX in free form. The ChOX and AuNP-ChOX bionanocomplex were analyzed in two environments: suspended in the phosphate buffer (as the optimal environment) and in the solid form. The main aim is to obtain the comprehensive information about the molecular structure of the enzyme and to determine the impact of the nanoparticle-protein interaction on the structure of the ChOX enzyme. The identification of changes occurring as a result of the connection of the ChOX with the AuNPs is important in the context of the bionanocomplexes development and their practical use in the biosensors.

\section{Experimental}

The sample preparation

The cholesterol oxidase enzyme was purchased from the Roche Diagnostics (Germany) company in the form of the lyophilized powder. The enzyme was produced by the Brevibacterium sp. Chemicals used for the AuNPs preparation and the ChOX immobilization were acquired from the Sigma Aldrich (USA) and the Avantor Performance Materials (Poland).
For the IR spectroscopy measurement of the ChOX in the solid form, the lyophilized powder did not require the prior preparation. To study the structure of the $\mathrm{ChOX}$ in the aqueous environment, it was dissolved in the $50 \mathrm{mM}$ phosphorous buffer, $\mathrm{pH} 7.5$ - the optimal conditions for the ChOX catalytic activity. The enzyme was highly concentrated $(5 \mathrm{mg} / \mathrm{ml})$.

The AuNP-ChOX bionanocomplexes were prepared by the covalent binding of the AuNP and the ChOX via a mercaptohexadecanoic acid (MHDA) liner (Wojnarowska et al. 2015a, b). The AuNPs were chosen as the most appropriate plasmonic materials, which are chemically inerted and does not have the adverse effect on the ChOX enzyme activity (in contrast to the silver) (MacLachlan et al. 2000).

In the first step of the bionanocomplex preparation, the AuNPs are synthesized by the reverse Turkevich method (Turkevich et al. 1951; Herizchi et al. 2016). The $1 \mathrm{mM}$ $\mathrm{HAuCl}_{4}$ was used as a substrate. The $34 \mathrm{mM}$ sodium citrate was a reducing agent as well as a stabilizer. The sodium citrate reagent (the $4.75 \mathrm{ml}$ ) was heated during $10 \mathrm{~min}$ at $100{ }^{\circ} \mathrm{C}$. Afterwards, the $0.25 \mathrm{ml}$ of the $\mathrm{HAuCl}_{4}$ was added. The synthesis was carried out for $15 \mathrm{~min}$ at $100{ }^{\circ} \mathrm{C}$. After cooling, the nanoparticles were purified by the 20 min centrifugation $(15,000 \mathrm{rpm})$ and washed twice with the deionized water.

The next stage of the bionanocomplexes preparation was the attachment to the AuNPs surface, the MHDA linker molecule. The AuNPs were incubated overnight at $4{ }^{\circ} \mathrm{C}$ with the $100 \mu \mathrm{l} 5 \mathrm{mM}$ MHDA solution. The conjugate was rinsed with the N,N-dimethylformamid (DMF) $(100 \mu \mathrm{l} \mathrm{DMF}, 15000 \mathrm{rpm}, 20 \mathrm{~min})$ and activated within $30 \mathrm{~min}$ at $25{ }^{\circ} \mathrm{C}$ by using the $100 \mu \mathrm{l}$ of the activation reagent: the $20 \mathrm{mM}$ N-cyclohexyl-N'-(2morpholinoethyl)-carbodiimidemetho-ptoluenesulfonate (CMC), the $20 \mathrm{mM}$ pentafluorophenyl-4-vinylbenzoate (PFP), the $20 \mathrm{mM}$ N,N-diisopropylethylamine (DIPEA), and the dissolved in DMF. The activated AuNP-MHDA complex was mixed with the $100 \mu \mathrm{l}$ of the $1 \mathrm{mg} / \mathrm{ml}$ ChOX solution and the $50 \mu \mathrm{l} \mathrm{DMF}$ and incubated during $1 \mathrm{~h}$ time at $25^{\circ} \mathrm{C}$. During the incubation, the sample was mixed. The prepared bionanocomplex was washed and suspended in the phosphate buffer (the $50 \mathrm{mM}, \mathrm{pH} 7.5$ ) to obtain the $0.5 \mathrm{mg} / \mathrm{ml}$ concentration of the ChOX enzyme.

The AuNP-ChOX bionanocomplex characterization

The prepared AuNPs and AuNP-ChOX bionanocomplex were characterized by the microscopic and the 
spectroscopic method. The size and the shape of the nanomaterials were determined using the Innova AFM microscope (Bruker, USA)). The $20 \mu \mathrm{l}$ aliquot of the tested sample was spread on the surface of the freshly cleaved mica, dried in gentle stream of the nitrogen, washed in the ultrapure distilled water, dried again, and analyzed in the air. The measurements were carried out with the use of the tapping mode and the super sharp TESP-SS cantilever. The tip resonance frequency of $290 \mathrm{kHz}$, the scan rate of $0.5 \mathrm{~Hz}$, and the resolution of the $512 \times 512$ pixels were selected.

The location of the SPR band for the AuNPs and the bionanocomplex was determined by the UV-VIS spectroscopic technique. The absorption spectra were obtained using the Evolution ${ }^{\mathrm{TM}} 300$ spectrometer (Thermo Scientific, USA). The measurement was carried out in the range from 350 to $800 \mathrm{~nm}$, with the resolution of $1 \mathrm{~nm}$. The analyzed AuNPs and the bionanocomplex samples were placed in a spectrophotometric quartz cuvette with an optical path length of $10 \mathrm{~mm}$.

To examine the effectiveness of the ChOX enzyme binding, the Lowry method of the biochemical determination of the protein concentration was used (Lowry et al. 1951). The determination of the concentration of the unbound protein gives the information about the amount of the ChOX attached into the bionanocomplex. The $0.125 \mathrm{ml}$ sample was mixed with the $0.75 \mathrm{ml}$ reagent I (the solution $\mathrm{A}$ - the $2 \% \mathrm{Na}_{2} \mathrm{CO}_{3}$ in the $0.1 \mathrm{M} \mathrm{NaOH}$, the solution $\mathrm{B}$ - the $0.5 \% \mathrm{CuSO}_{4}$ in the $1 \%$ sodium citrate solution, a ratio of 49:1). After the 10-min incubation, the $0.075 \mathrm{ml}$ of Folin-Ciocalteu reagent was added. The samples were mixed and incubated $40 \mathrm{~min}$ in the dark, at room temperature. The absorbance was measured at the $750 \mathrm{~nm}$ against the control sample. For the preparation of the standard curve, the bovine serum albumin (BSA) was used (the $0.025 \mathrm{mg} / \mathrm{ml}$, the $0.05 \mathrm{mg} / \mathrm{ml}$, the $0.1 \mathrm{mg} / \mathrm{ml}$, the $0.2 \mathrm{mg} / \mathrm{ml}$, and the $0.5 \mathrm{mg} / \mathrm{ml}$ of the BSA).

The ChOX enzymatic activity was determined in the biochemical reaction of the cholesterol transformation to the 4-cholesten-3-one. The production of the $\mathrm{H}_{2} \mathrm{O}_{2}$ during the reaction was monitored in the horseradish peroxidase-catalyzed reaction by the oxidation of the o-dianisidine, which caused a change in its color. The reaction mixture consisted of the $1.2 \mathrm{ml} 0.01 \%$ odianisidine, the $0.1 \mathrm{ml} 0.5 \%$ cholesterol, the $0.1 \mathrm{ml}$ horseradish peroxidase in the phosphate buffer (the $50 \mathrm{mM}, \mathrm{pH} 7.0$ ), and the $0.1 \mathrm{ml} \mathrm{ChOX}$ (free or in the bionanocomplex form). The colorimetric measurement was performed at $500 \mathrm{~nm}$ with the use of the Evolution
300 (Thermos Scientific) spectrometer and calculated to the ChOX enzyme activity.

The FTIR spectra recording

The FTIR spectra were recorded by the Vertex $70 \mathrm{v}$ (Bruker, USA) and the FTIR spectrometer with the use of the Attenuated Total Reflectance (ATR) technique. The ATR instrument is equipped with a diamond crystal. The samples were placed on the crystal surface: the amount of the lyophilized ChOX powder, the $10 \mu \mathrm{l}$ of liquid samples of the ChOX in the buffer solution, the thin film of the AuNP-ChOX bionanocomplex, and the $10 \mu 1$ of liquid samples of the AuNP-ChOX bionanocomplex in the buffer solution. The samples were kept in the good optical contact with the diamond crystal surface. The measurements were performed in the region of the middle infrared $\left(800-4000 \mathrm{~cm}^{-1}\right)$ using 64 scans of the provided spectral resolution of the $1 \mathrm{~cm}^{-1}$, at room temperature. For the spectrum collection and the data processing, the software OPUS 6.0 (Bruker) was used. The background of a blank diamond was used to generate the absorption spectra of the researched samples. The buffer spectra were recorded additionally, in order to subtract from the obtained spectrum of the enzyme suspended in the solution. The baseline correction (the rubber band correction) and the normalization (intensity range) were implemented. The second derivative spectra were calculated by the use of the Savitzky-Golay method. They were used to estimate the contribution of the individual lines composing amide I band (1590-17,100 $\mathrm{cm}^{-1}$ ) and gave the information about the secondary structure of the enzyme. The obtained information was taken into an account to fit the band by the Lorenzian and Gaussian functions.

\section{Results and discussion}

The AuNP-ChOX bionanocomplex characterization

\section{The size and the optical properties}

The size and the shape of the AuNP nanoparticles are determined in the production process. They depend on the concentration and the type of the reducer, as well as, on the reaction conditions. The prepared AuNPs and the bionanocomplex were examined by the AFM microscopy. As is seen in Fig. 1, the AuNPs have the spherical 
shape and the diameter of about $55 \mathrm{~nm}$ (the size ranges from 42 to $68 \mathrm{~nm}$ with 7.5 standard deviation). The approximate molar concentration and the concentration of the NPs per $\mathrm{mL}$ of the suspension were defined as $2.9 \mathrm{mmol} / \mathrm{L}$ and $3.4 * 10^{11} \mathrm{NP} / \mathrm{mL}$, respectively.

The biofunctionalization process, resulting in the AuNP-ChOX bionanocomplex formation, is associated with the change in the size and the shape of the nanoparticles. An increase in the size of the formed complexes was observed. The attachment of the linker and the protein results in the creation of the more aggregated forms. The shape is more irregular, which is seen in Fig. 1.

The position of the SPR band in the AuNPs and the AuNP-ChOX bionanocomplexes are presented in Fig. 2. The change in the position of the absorption maximum and the shape of the band were observed. The absorption maximum corresponding to the plasmon frequency is clearly visible at the $525 \mathrm{~nm}$ for the AuNP and at the $594 \mathrm{~nm}$ for the bionanocomplex. The high plasmonic activity occurs in the region, which is close to the location of the maximum absorption (Amendola et al. 2017). The SPR band shifts towards the longer waves. The red shift is associated with the mentioned change in the size of the nano-objects (the increase in the particle diameter) and the presence of a coating on the surface of the nanoparticles. This results in the transfer of the electrons from the AuNP to the ligand (Ravindran et al. 2010), which means the decrease in the concentration of the electrons in the AuNP matrix, as well as, a reduction in the plasmonic frequency. The change of the SPR band position is affected also by the change in the local environment around the nanoparticle. For the monodisperse suspensions, the half width of the absorption band (FWHM) is several dozen nanometers. The observed bandwidth extension is connected with the increase of the nanoparticles diameter and the higher sample heterogeneity.

\section{The enzyme catalytic activity}

The preservation of the catalytic activity is confirmed also by the biochemical tests carried out for the free forms of the ChOX and the investigated bionanocomplex. The obtained values of the catalytic activity of the AuNPChOX bionanocomplex $(3.53 \mathrm{U} / \mathrm{mg})$ is lower than the initial activity of the unbound enzyme $(6.01 \mathrm{U} / \mathrm{mg})$, but it is still satisfactory. The reduction of the enzyme activity in
Fig. 1 The AFM images of the AuNPs in a the height mode and b the tapping amplitude mode, and the AFM images of the AuNP-ChOX bionanocomplex in $\mathbf{c}$ the height mode and $\mathbf{d}$ the tapping amplitude mode
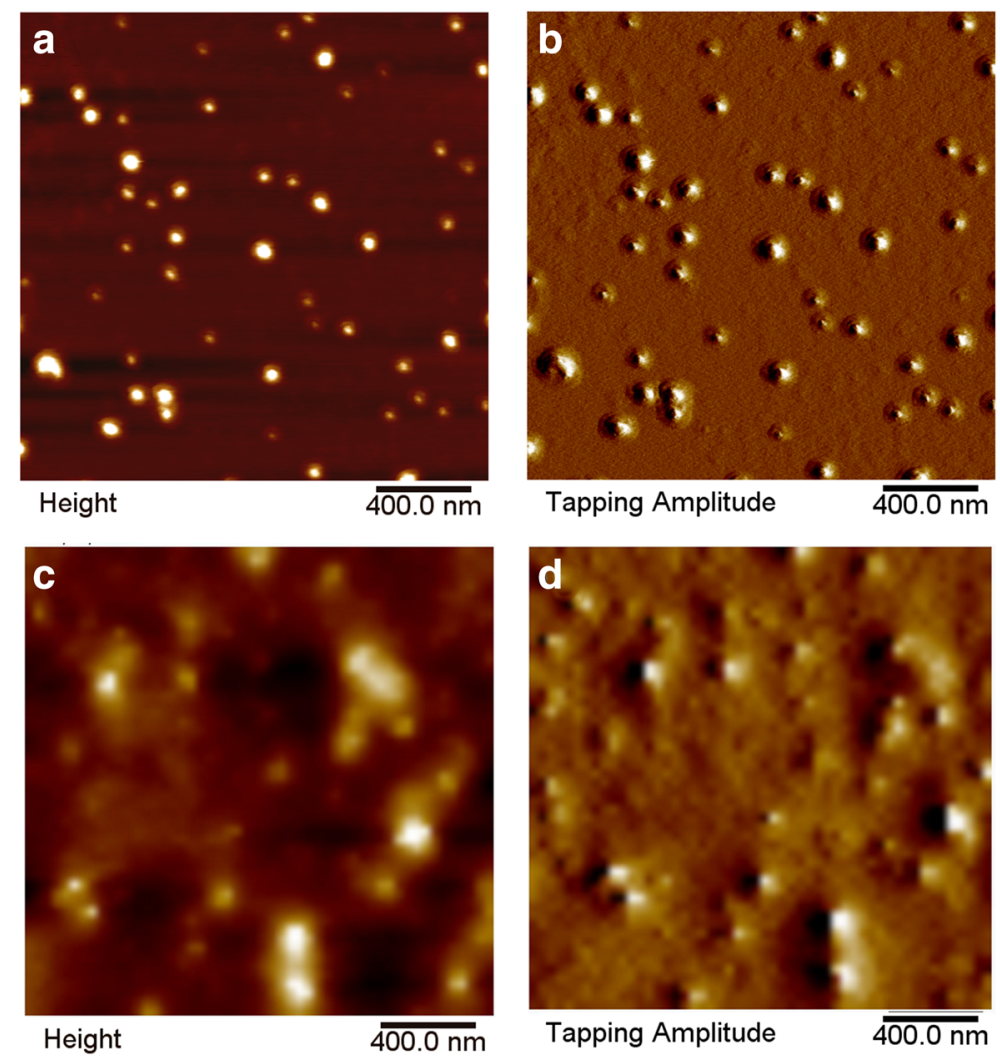


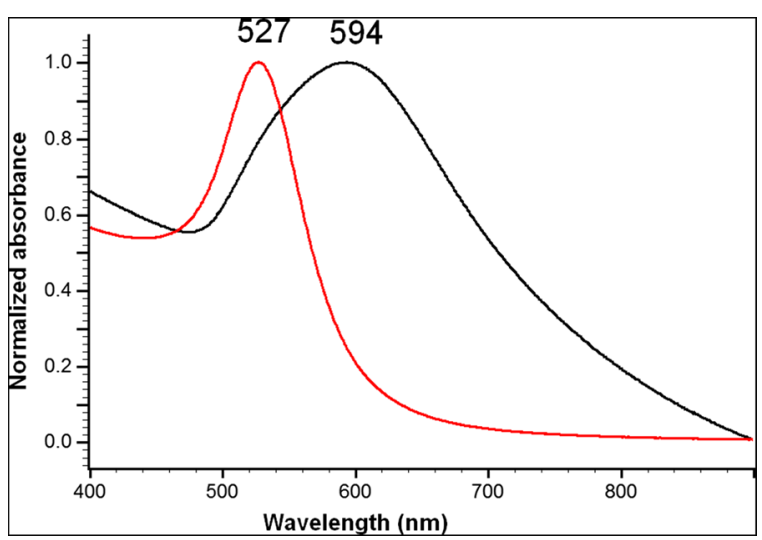

Fig. 2 The SPR bands of the AuNPs (the red curve) and the AuNP-ChOX bionanocomplexes (the black curve)

the case of the immobilized enzyme is influenced by the various factors. One of them may be the reduction of the availability of the binding sites for the substrate through binding to the surface of the carrier. In addition, the inactivation of some of the enzyme molecules during the synthesis process may appear.

The next element of the AuNP-ChOX bionanocomplexes characterization was the determination of the efficiency of the enzyme attachment to the nanoparticles surface. The ChOX was binding with the NPs by using the MHDA linker. This organic molecule have the linear structure (the size: $2.35 \mathrm{~nm}$ ) and the two functional groups at the ends of the molecule: the thiol group and the carboxy group. Due to the use of the protein concentration of $1 \mathrm{mg} / \mathrm{ml}$, the binding efficiency was about $95 \%$. The stability of the connection between the nanoparticle and the enzyme is good. The AuNP-ChOX bionanocomplex was rinsed several times with the phosphate buffer, but no presence of the ChOX in the rinse solution was noted. The covalent connection of the nanoparticle-linker and the linker-ChOX is strong enough so that it does not break during the washing. The bionanocomplex can be reused (and even several times).

The FTIR spectroscopy analysis

The FTIR spectra of the ChOX in the solid form and suspended in the buffer as the reference spectra of the free enzyme

The FTIR spectra of the ChOX in the free form: the solid and the suspended in the buffer are presented in Fig. 3. Due to the high complexity of the enzyme structure, which generates a large amount of vibrations, an accurate identification of each band is difficult. However, the obtained spectra possess the typical spectral bands, which are the most significant for the proteins: the amides I, II, and III, as well as the amides A and B (Barth 2000; Malek et al. 2014). It has been observed that the change in the environment affects some modifications in the position and in the intensity of the registered bands. In Table 1, the positions of the observed bands and their identification are collected.

The spectrum range from 3500 to $3000 \mathrm{~cm}^{-1}$ contains a few overlapping lines derived from the different chemical bonds. The bands observed at the $3283 \mathrm{~cm}^{-1}$ and at about the $3060 \mathrm{~cm}^{-1}$ in the solid $\mathrm{ChOX}$ are associated with the amide $\mathrm{A}$ and amide $\mathrm{B}$, respectively. They are attributed to the stretching vibration of the $\mathrm{NH}$ group (Barth 2007; Kong and Yu 2007). The lines with a maximum at about the $3220 \mathrm{~cm}^{-1}$ and the $3490 \mathrm{~cm}^{-1}$ are associated with the $\mathrm{OH}$ hydroxyl group in the bonded and in the nonbonded form (Coates 2000). The maximum of the band described as the amide $\mathrm{A}$ and $\mathrm{B}$ region is shifted from at around $3250 \mathrm{~cm}^{-1}$ to $3420 \mathrm{~cm}^{-1}$ for the ChOX in the buffer. These lines are sensitive to the hydrogen bond presence; however, they are not related to the polypeptide backbone (Barth 2007).

The amide I band is observed at the $1645 \mathrm{~cm}^{-1}$ for the ChOX in the solid form and the $1640 \mathrm{~cm}^{-1}$ for the ChOX in the buffer, and it derives mainly from the stretching vibration of the peptide carbonyl group $\mathrm{C}=\mathrm{O}$, with the minor influence of the out-of-phase $\mathrm{CN}$ stretching, the C-C-N deformation, and the NH in-plane vibrations (Kong and Yu 2007; Spalding et al. 2018). The position and the shape of the amide I band are dependent on the secondary structure of the protein backbone. Another important band is the associated with the amide II band and occurs at the $1542 \mathrm{~cm}^{-1}$ and the $1546 \mathrm{~cm}^{-1}$ for the solid and the suspended ChOX form, respectively. It derives mainly from the in-plane $\mathrm{NH}$ bending (40-60\%) and from the $\mathrm{CN}$ stretching vibrations with the small contributions from the $\mathrm{CO}$ in the plane bending, the $\mathrm{CC}$, and the $\mathrm{NC}$ stretching vibrations. The secondary structure of the protein has smaller influence on this band than on the amide I. The shoulder at the $1518 \mathrm{~cm}^{-1}$ related to the tyrosine amino acid is more visible in Fig. 3b. The amide III band (at about the $1250 \mathrm{~cm}^{-1}$ ) is a combination of the several modes including the side chain structure vibrations, the $\mathrm{NH}$ bending vibration, and the other similar ones like in the amide II (Barth 2007). The other 

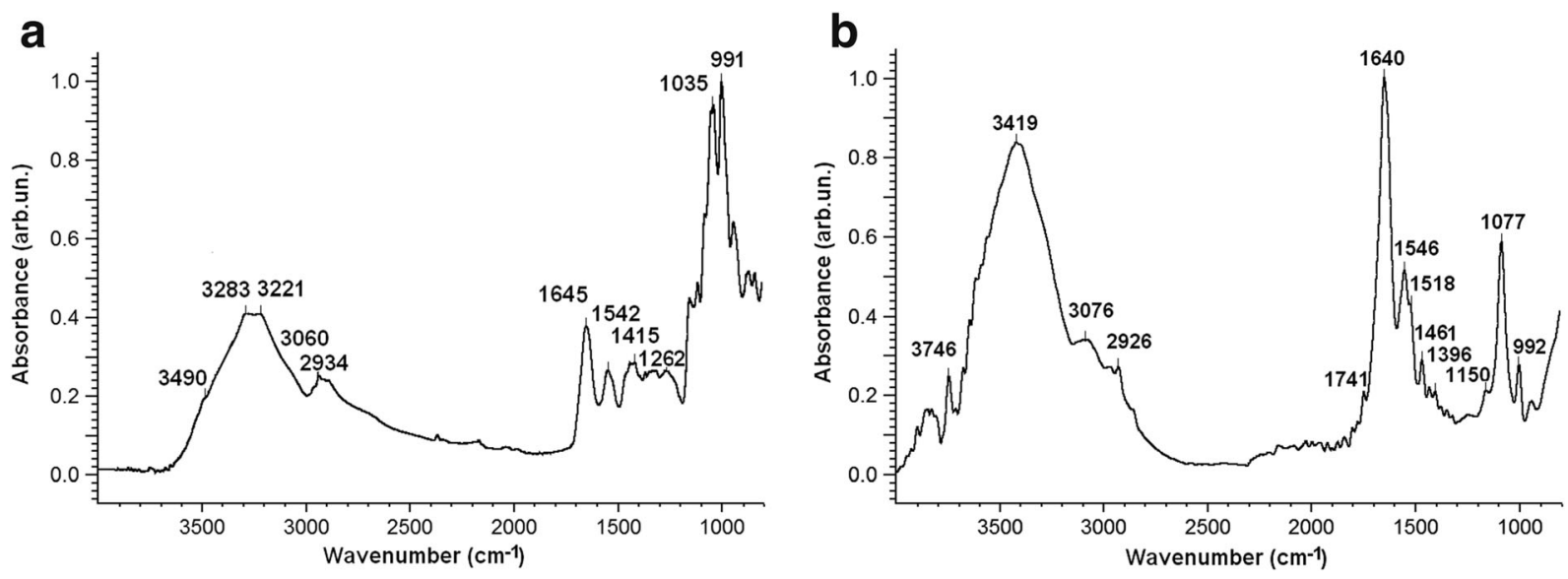

Fig. 3 The FTIR spectra of the cholesterol oxidase: $\mathbf{a}$ in the solid form and $\mathbf{b}$ suspended in the phosphate buffer

amide bands (the amide IV-the amide VII) are difficult for detailed analysis. They are located in the range of the 200-800 $\mathrm{cm}^{-1}$, which belongs to the fingerprint region - unique to each molecule, which is rich in the vibrations of the molecule skeleton, the proteinous, and the nonproteinous parts (Coates 2000; Barth and Zscherp 2002). Additionally, the amide III-VII bands are strongly dependent on the details of the force field,

Table 1 The identification of the lines observed in the FTIR spectra of the ChOX

\begin{tabular}{|c|c|c|c|c|}
\hline ChOX solid & ChOX in buffer & $\begin{array}{l}\text { ChOX-AuNP } \\
\text { solid }\end{array}$ & $\begin{array}{l}\text { ChOX-AuNP in } \\
\text { buffer }\end{array}$ & Identification \\
\hline \multirow[t]{2}{*}{$3000-3500(\mathrm{~s})$} & $3150-3700(\mathrm{~s})$ & $3000-3700(\mathrm{~s})$ & $3300-3700(\mathrm{~m})$ & $v(\mathrm{~N}-\mathrm{H})$ (amide $\mathrm{A}, \mathrm{B}) ; v(\mathrm{O}-\mathrm{H})$ \\
\hline & $3076(\mathrm{~m})$ & & $3063(\mathrm{~s})$ & $v(\mathrm{~N}-\mathrm{H})($ amide $\mathrm{B})$ \\
\hline $\begin{array}{l}2959,2934,2907 \\
2886(\mathrm{~m})\end{array}$ & $\begin{array}{r}2965,2926 \\
2852(\mathrm{~m})\end{array}$ & $\begin{array}{l}2925,2854 \\
(\mathrm{~m})\end{array}$ & $\begin{array}{l}2945,2912,2843 \\
\quad(\mathrm{~m})\end{array}$ & $v_{\mathrm{as}}(\mathrm{C}-\mathrm{H}), v_{\mathrm{s}}(\mathrm{C}-\mathrm{H})$ \\
\hline- & $1741(w)$ & - & $1743(w)$ & $\mathrm{C}=\mathrm{O}$ \\
\hline $1645(\mathrm{~s})$ & $1640(s)$ & $1642(s)$ & $1643(s)$ & Amide I $(v(\mathrm{C}=\mathrm{O}), v(\mathrm{CN}), \mathrm{CCN}$ deformation, $\mathrm{NH}$ bend $)$ \\
\hline $1542(\mathrm{~m})$ & $1546(\mathrm{~m})$ & $1540(\mathrm{~m})$ & $1544(\mathrm{~m})$ & Amide II (NH bend, $\vee(\mathrm{CN}), \mathrm{CO}$ in plane, $\mathrm{CC}, \vee(\mathrm{NC}))$ \\
\hline- & $1518(\mathrm{~m})$ & $1510(\mathrm{sh})$ & $1512(\mathrm{sh})$ & $\begin{array}{l}v(\mathrm{C}=\mathrm{C}) \text { and } \mathrm{C}-\mathrm{H} \text { bend vibrations characteristic for tyro- } \\
\quad \text { sine }\end{array}$ \\
\hline $\begin{array}{l}1454(\mathrm{w}), 1434 \\
\quad(\mathrm{~m})\end{array}$ & $\begin{array}{l}\text { 1461(m), } \\
\text { 1427(m) }\end{array}$ & $1459(\mathrm{~m})$ & $1458(\mathrm{~m}), 1425(\mathrm{~m})$ & $\delta\left(\mathrm{CH}_{2}\right), \delta_{\mathrm{as}}\left(\mathrm{CH}_{3}\right)$ \\
\hline $1415(\mathrm{~m})$ & - & - & - & $v_{\mathrm{s}}\left(\mathrm{COO}^{-}\right), v(\mathrm{CN})$ \\
\hline $1300-1400(w)$ & $1300-1400(w)$ & $1359(w)$ & $1367(w)$ & $v_{\mathrm{s}}\left(\mathrm{COO}^{-}\right)$and $\delta(\mathrm{C}-\mathrm{H}), \mathrm{O}-\mathrm{H}$ bend, $\delta_{\mathrm{s}}\left(\mathrm{CH}_{3}\right), v(\mathrm{CN})$ \\
\hline$\sim 1262(\mathrm{w})$ & $\sim 1237(\mathrm{w})$ & $1258(\mathrm{w})$ & $\sim 1250(\mathrm{w})$ & $\begin{array}{l}\text { Amide III }(v(\mathrm{CN}), \mathrm{NH} \text { bend, } \mathrm{CO} \text { in plane, } v \\
(\mathrm{CC})) \text {, similar amino acids side chains vibrations, } \\
v_{\mathrm{as}}\left(\mathrm{PO}_{2}^{-}\right) \text {from FAD }\end{array}$ \\
\hline $1149(\mathrm{~m})$ & $1150(\mathrm{~m})$ & $1120(\mathrm{sh})$ & $1150(\mathrm{~m})$ & $v(\mathrm{C}-\mathrm{C})$ \\
\hline $1107(\mathrm{~m})$ & - & - & - & $v(\mathrm{C}-\mathrm{C}), \gamma(\mathrm{C}-\mathrm{O}), \gamma\left(\mathrm{CH}_{2}\right)$ \\
\hline $1076(\mathrm{~m})$ & $1077(\mathrm{~m})$ & $1051(\mathrm{~s})$ & $1080(\mathrm{~s})$ & $\begin{array}{l}v_{\mathrm{s}}\left(\mathrm{PO}_{2}^{-}\right) \text {from } \mathrm{FAD}, v(\mathrm{C}-\mathrm{O}), v(\mathrm{CN}) \text { from amino } \\
\quad \text { acids side chains }\end{array}$ \\
\hline $1043,1032(\mathrm{~s})$ & - & - & - & $v(\mathrm{C}-\mathrm{O})$ \\
\hline $991(\mathrm{~s})$ & $992(\mathrm{~m})$ & $983(\mathrm{~m})$ & $990(\mathrm{~m})$ & $v(\mathrm{P}-\mathrm{O}-\mathrm{C}), v(\mathrm{C}-\mathrm{O})$ from $\mathrm{FAD}$ \\
\hline $934(\mathrm{~m})$ & $935(\mathrm{~m})$ & $941(\mathrm{~m})$ & $922(w)$ & $\mathrm{C}-\mathrm{C}, \mathrm{v}(\mathrm{C}-\mathrm{O})$ \\
\hline $867(w)$ & $\sim 850(\mathrm{w})$ & 862 & $\sim 850(\mathrm{w})$ & $\mathrm{O}-\mathrm{H}$ out of plane bending \\
\hline
\end{tabular}

$s$ strong, $m$ medium, $w$ weak, $s h$ shoulder, $\nu$ stretching vibration, $\nu_{s}$ symmetric stretching vibration, $\nu_{a s}$ antisymmetric stretching vibration, $\delta$ in plane bending vibration, $\delta_{a s}$ asymmetric in plane bending vibration 
the nature of the side chains, and the hydrogen bonding (Kong and Yu 2007).

The local environment has a significant influence on the $\mathrm{C}-\mathrm{H}$ vibration modes. The lines attributed to the $\mathrm{C}-\mathrm{H}$ bonds are observed approximately at the $2900 \mathrm{~cm}^{-1}$ and the $1400 \mathrm{~cm}^{-1}$. The asymmetric and the symmetric stretching vibration of the $\mathrm{CH}_{2}$ group (the $2934 \mathrm{~cm}^{-1}$ / $2926 \mathrm{~cm}^{-1}$ and the $2850 \mathrm{~cm}^{-1} / 2852 \mathrm{~cm}^{-1}$ ) as well as the asymmetric stretch of the $\mathrm{CH}_{3}$ group $\left(2959 \mathrm{~cm}^{-1} /\right.$ $2965 \mathrm{~cm}^{-1}$ ) (Coates 2000; Malek et al. 2014; Malek 2016) are observed with the higher intensity in the IR spectrum of the ChOX suspended in the buffer than in the solid form of the enzyme. The peaks attributed to the symmetric stretch of the $\mathrm{CH}_{3}$ (the $2886 \mathrm{~cm}^{-1}$ ) and the $\mathrm{CH}$ stretch (the $2907 \mathrm{~cm}^{-1}$ ) (Coates 2000; Stuart 2004; Malek et al. 2014) are not clearly visible on the spectrum of the suspended enzyme. The intensity of the lines attributed to the $\delta\left(\mathrm{CH}_{2}\right)$ and the $\delta_{\text {as }}\left(\mathrm{CH}_{3}\right)$ modes (the $1470 \mathrm{~cm}^{-1} /$ $1461 \mathrm{~cm}^{-1}$ and the $1430 \mathrm{~cm}^{-1} / 1427 \mathrm{~cm}^{-1}$ ) are significantly higher for the $\mathrm{ChOX}$ in the buffer. The band attributed to the $\delta_{\mathrm{s}}\left(\mathrm{CH}_{3}\right)$ mode is shifted depending on the environment (the $1385 \mathrm{~cm}^{-1} / 1396 \mathrm{~cm}^{-1}$ ). The week bands are located in the region of the wagging the $\mathrm{CH}_{2}$ and the bending $\mathrm{CH}$ vibrations (the $1300-1400 \mathrm{~cm}^{-1)}$ (Ivanov et al. 1994; Coates 2000; Stuart 2004; Barth 2007; Malek 2016) and should be referred to them.

The other observed bands can be assigned to the chemical group of the amino acids, the molecule skeleton or the FAD cofactor. As mentioned in "Introduction," the ChOX is the FAD-dependent enzyme (Vrielink 2010). The analyzed spectra contain the vibration bands derived from the FAD molecule. The symmetric $v_{\mathrm{s}}\left(\mathrm{PO}_{2}{ }^{-}\right)$stretching vibration is found at the $1076 \mathrm{~cm}^{-1} / 1077 \mathrm{~cm}^{-1}$. The line observed at the $991 \mathrm{~cm}^{-1}$ could be assigned to the P-O and the P-O-C vibrations (Coates 2000, Stuart 2004). The similar lines can be observed in the other flavoproteins, e.g. in the glucose oxidase spectrum (Delfino et al. 2013) (but not for the other types of the proteins e.g. the albumin) (Tabassum et al. 2012). The lines attributed to the isoalloxazine ring and the adenosine are located in the range from the $1500 \mathrm{~cm}^{-1}$ to the $1720 \mathrm{~cm}^{-1}$, which is characteristic for the amide I and the amide II bands. The $v_{\mathrm{as}}\left(\mathrm{PO}_{2}{ }^{-}\right)$vibration gives the line at around the $1250 \mathrm{~cm}^{-1}$ (Spexard et al. 2011; Spalding et al. 2018) and overlaps with the amide III band.

Due to the high complexity of the protein molecule, many bands derived from the amino acid side chains overlapped, which prevents their unambiguous interpretation. For example, some of the amino acid IR lines occur in the amide I region: the $v(\mathrm{C}=\mathrm{O})$ vibration of the glutamic acid and the glutamine (Barth 2000; Stuart 2004), the $v_{\text {as }}\left(\mathrm{CN}_{3} \mathrm{H}_{5}{ }^{+}\right)$and the $\gamma_{\mathrm{s}}\left(\mathrm{CN}_{3} \mathrm{H}_{5}{ }^{+}\right)$ modes of the arginine (Barth 2000; Barth 2007), the $v(\mathrm{C}=\mathrm{C})$ mode of the tryptophan and the histidine (Barth 2000; Wolpert and Hellwig 2006), and the $\delta$ $\left(\mathrm{NH}_{2}\right)$ of the asparagines (Barth 2000). Similarly, it concerns the amide II: the $\mathrm{v}_{\text {as }}\left(\mathrm{COO}^{-}\right)$and the aspartic acid (Barth 2000) and the $v\left(\mathrm{COO}^{-}\right)$of the glutamic acid (Wolpert and Hellwig 2006). Only some bands can be attributed to the vibrations of the side chains of the amino acids: the line at the $1743 \mathrm{~cm}^{-1}$ is associated with the $v(\mathrm{C}=\mathrm{O})$ aspartic acid vibration (Stuart 2004) as well as the line at the $1518 \mathrm{~cm}^{-1}$ could be assigned to the $v(\mathrm{C}=\mathrm{C})$ and the $\delta(\mathrm{C}-\mathrm{H})$ vibrations of the tyrosine (Barth 2000).

\section{The FTIR spectra of the ChOX in the bionanocomplex}

Figure 4 shows the oscillation spectrum of the AuNPChOX bionanocomplex in thin film form (Fig. 4a) and suspended in phosphate buffer (Fig. 4b) with the size of the AuNP approximately $55 \mathrm{~nm}$. The main lines are characterized in Table 1, and they are consistent with the previously received data (the subchapter "The FTIR spectra of the ChOX in the solid form and suspended in the buffer as the reference spectra of the free enzyme"). The most important lines are presented in the similar positions in all form of the ChOX, which confirms only the slight structural changes caused by the change of the environment and the immobilization process. The amide I band in the AuNP-ChOX bionanocomplex is observed at the $1642 \mathrm{~cm}^{-1}$ and $1643 \mathrm{~cm}^{-1}$, which indicates the preservation of the native secondary structure of the ChOX. A detailed analysis of the protein secondary structure is presented in the next subchapter (see "The secondary structure of the ChOX"). A small broadening of the amide I line is registered. It is associated with the occurrence of the molecular interactions between the nanoparticle and the ChOX via the MHDA linker. As it is described by Talat et al. (2011), it confirms the covalent connection of the nanoparticles and the proteins as well as the bionanocomplex formation.

The amide II band $\left(1540 \mathrm{~cm}^{-1}\right.$ and $\left.1544 \mathrm{~cm}^{-1}\right)$ is also only slightly modified, and it is close to the corresponding maximum for the free enzyme with the shift of $2 \mathrm{~cm}^{-1}$ for both environments: solid in air and suspended in buffer. This band is more sensitive to 
changes of the local environment resulting in the difference in the shape of the band. The line associated with the tyrosine vibration $\left(1510 \mathrm{~cm}^{-1}\right.$ and $1512 \mathrm{~cm}^{-1}$ ) (Barth 2007) is observed as the shoulder of the amide II band in both bionanocomplex forms. The maximum of the amide III band is observed at the $1259 \mathrm{~cm}^{-1}$ for solid bionanocomplex and at about $1250 \mathrm{~cm}^{-1}$ for bionanocomplex suspended in buffer. It is shifted by $3 \mathrm{~cm}^{-1}$ in relation to the solid form of the ChOX. The dried AuNP-ChOX samples indicated strong similarity to the free enzyme in the solid form. In the case of the ChOX enzyme and bionanocomplex in suspended form, some spectral line shifts and changes in the intensity of some bands can be seen, but they are close to each other.

A broadening of the bands in the region from the 3000 to the $3700 \mathrm{~cm}^{-1}$ attributed to the amide $\mathrm{A}$ and the amide $\mathrm{B}$, and the $\mathrm{O}-\mathrm{H}$ stretching vibration of the bionanocomplex in solid form should be noted. The frequency of the vibrations depends on the occurrence of the hydrogen bond, so their changes are strongly connected with the local environment but should not reduce the enzymatic functionality.

In the region from the 1500 to the $800 \mathrm{~cm}^{-1}$ called the fingerprint region, the most noticeable changes of spectra shape are observed. The P-O-C vibration line attributed to the FAD cofactor is clearly visible at the $983 \mathrm{~cm}^{-1}$ and $990 \mathrm{~cm}^{-1}$ for solid and suspended in buffer AuNP-ChOX bionanocomplex, respectively. The confirmation of the FAD presence is very important because this molecule is necessary for the ChOX catalytic activity. Despite the high variability of the fingerprint region, the quite constant position of the P-O-C band allows the employment of it as the marker line to determine the classification of the unknown protein to the flavoprotein class.

The presence of the linker structure have an impact on recorded spectrum in the $\mathrm{CH}$ vibration regions. The AuNP-MHDA spectrum is richer in the lines attributed to the stretching $v\left(\mathrm{CH}_{2}\right)$ (at the $2914 \mathrm{~cm}^{-1}$ and at the $\left.2848 \mathrm{~cm}^{-1}\right)$ and bending the $\delta\left(\mathrm{C}-\mathrm{H}_{2}\right)$ (the $1472 \mathrm{~cm}^{-1}$ and the $1407 \mathrm{~cm}^{-1}$ ) vibrations (Wojnarowska et al. 2015b). It affects the modification of the intensity of the IR bands associated with the vibrations of $\mathrm{C}-\mathrm{H}$ bonds. Therefore, they are not subject to the analysis of the ChOX after immobilization. The $v_{\mathrm{as}}\left(\mathrm{CH}_{2}\right) / v_{\mathrm{s}}\left(\mathrm{CH}_{2}\right)$ lines of the bionanocomplex (at the $2925 / 2912 \mathrm{~cm}^{-1}$ and at the $2854 / 2843 \mathrm{~cm}^{-1}$ ) are amplified by the presence of the linker. The $\mathrm{C}-\mathrm{H}$ bending vibration modes localized in the fingerprint region are also modified.
The position of the main IR bands in the studied spectra of the ChOX enzyme is presented in Table 2. The most noticeable changes occur in the fingerprint region of dried AuNP-ChOX bionanocomplex in comparison with other forms of the ChOX enzyme. The shape of the spectra in the fingerprint region of free ChOX and bionanocomplex suspended in buffer are similar.

\section{The secondary structure of the ChOX}

In order to investigate the secondary structure of ChOX enzyme, the second derivative in the narrow amide I spectral region is applied. The lines forming this band are highly sensitive to the variation in the molecular geometry and the hydrogen bonding (Kong and Yu 2007; Machan et al. 2012). The spatial structure is important for the enzymes because their catalytic activity depends on its correctness due to the proper availability of the active sites (Walsh 2002; Barth 2007).

Figure 5 shows the $-\mathrm{d}^{2} \mathrm{~A} / \mathrm{d} v^{2}$ normalized spectrum for the spectral region from the 1590 to the $1710 \mathrm{~cm}^{-1}$ and the deconvolution of the amide I band by the Lorentzian and Gaussian functions. The positions of the $-\mathrm{d}^{2} \mathrm{~A} / \mathrm{d} v^{2}$ maxima correspond to the positions of the individual spectral lines, which overlap and form the amide I band. The obtained peaks positions and their percentage are collected in Table 3. It can be seen that the shape of the amide I band is similar for the ChOX and the AuNP-ChOX bionanocomplex suspended in buffer.

In the spectrum of the ChOX suspended in the buffer as an optimal environment, the line located at the $1654 \mathrm{~cm}^{-1}$ is associated with the $\alpha$-helical protein structure (Barth 2007, Kong and Yu 2007; Castrignanò et al. 2012) and the relative area of its Lorentzian provides a concentration of the $27 \%$. The percentage of the $\beta$-sheets is $46 \%$, calculated by the relative area of the Lorentzian for the line at the $1693 \mathrm{~cm}^{-1}$, the $1635 \mathrm{~cm}^{-1}$, and the $1621 \mathrm{~cm}^{-1}$ (Barth 2007, Mobili et al. 2009; Paluszkiewicz et al. 2017). The $\alpha$-helix and the $\beta$-sheet are primary types of the protein secondary structure. The $\alpha$-helix is coiled in the righthanded structure and is stabilized by the hydrogen bonding, which occurs between the successive turns of the helix. In the $\beta$-sheet conformation, the amino acids lie either parallely or antiparallely to one another, and the hydrogen bonds are localized between the strands (Walsh 2002).

The other types of the spatial structure of the proteins are also registered. One of them is the $\beta$-turn structure, 

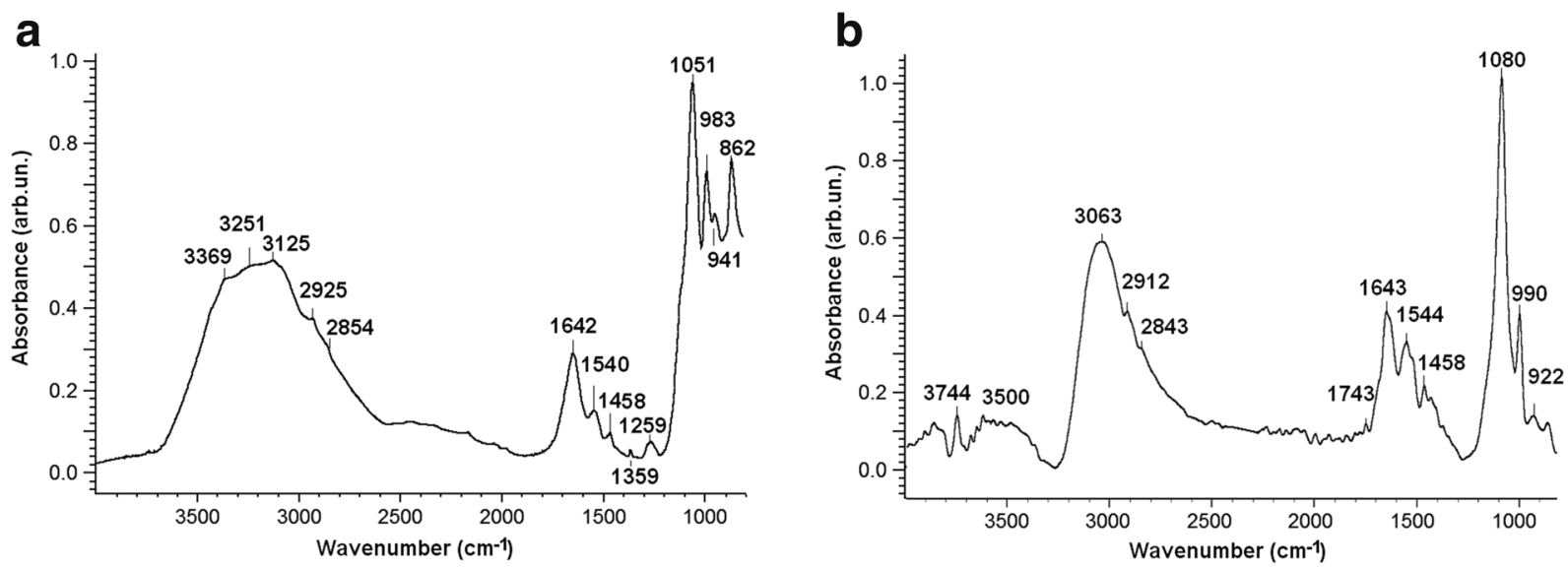

Fig. 4 The FTIR spectrum of the cholesterol oxidase immobilized on the gold nanoparticles: a dried film and $\mathbf{b}$ suspended in the phosphate buffer

which is the type of the nonregular secondary structure. It causes the change in direction of the polypeptide chain. The percentage of the $\beta$-turns in the ChOX in the buffer is about $16 \%$ and is associated with the area of lines at the $1685 \mathrm{~cm}^{-1}$ and the $1671 \mathrm{~cm}^{-1}$ (Kong and $\mathrm{Yu}$ 2007; Mobili et al. 2009). The band at the $1645 \mathrm{~cm}^{-1}$ is assigned to the random coil (Castrignanò et al. 2012; Delfino et al. 2013; Paluszkiewicz et al. 2017), which is the irregular protein structure $(\sim 17 \%)$. The bands originating from the amino acid side chains vibrations are also observed $\left(1614 \mathrm{~cm}^{-1}\right)$ (Barth 2007).

The positions of the bands and their percentage contribution corresponding to a given protein structure is very close to each other for the suspended form of the free and the immobilized ChOX enzyme. The $\alpha$-helical protein structure corresponds with the $1655 \mathrm{~cm}^{-1}$, and the percentage is $24 \%$, which is about $3 \%$ less than in the free enzyme. The percentage of the $\beta$-sheets is also about $46 \%$, calculated by the area of the line at the
$1699 \mathrm{~cm}^{-1}$, the $1636 \mathrm{~cm}^{-1}$, and the $1620 \mathrm{~cm}^{-1}$. The other types of the protein secondary structure constitute about $30 \%$ ( $\beta$-turn $-10 \%$, random $-17 \%$, amino acids side chains $-3 \%)$. The difference between free ChOX and bionanocomplexes is about $2 \%$.

The deconvolution of the amide I band solid form of the ChOX free and immobilized form shows the similar spectral lines; however, their maximum and the area are slightly changed. A shift in the frequency position is observed for the $\beta$-sheet structure characteristic lines (Table 3). This result indicates that the hydrogen bond strength differs. In Table 4, it can be noticed that the $\beta$ sheet structure is dominant in the $\mathrm{ChOX}$ in the aqueous solution, although it decreases in the solid and in the immobilized form. In these cases, the participation of the $\alpha$-helix and the $\beta$-sheet structure is similar. The contribution of the $\alpha$-helix is more constant (from approximately the 27 to the $33 \%$ ). The random coil contribution is changed in the significant way (around the

Table 2 The overview of the main IR lines of the ChOX in the different environmental conditions

\begin{tabular}{|c|c|c|c|c|}
\hline \multirow[t]{2}{*}{ IR band } & \multicolumn{4}{|c|}{ Position of line $\left(\mathrm{cm}^{-1}\right)$} \\
\hline & ChOX solid & ChOX in buffer & ChOX-AuNP solid & ChOX-AuNP in buffer \\
\hline Amide A & 3283 & 3282 & 3251 & 3300 \\
\hline Amide B & 3060 & 3076 & 3072 & 3063 \\
\hline Amide I & 1645 & 1640 & 1642 & 1643 \\
\hline Amide II & 1542 & 1546 & 1540 & 1544 \\
\hline Amide III & 1262 & 1237 & 1259 & 1250 \\
\hline$v_{\mathrm{s}}\left(\mathrm{PO}_{2}^{-}\right)$ & 1076 & 1077 & 1051 & 1080 \\
\hline $\mathrm{P}-\mathrm{O}-\mathrm{C}$ & 991 & 992 & 983 & 990 \\
\hline
\end{tabular}



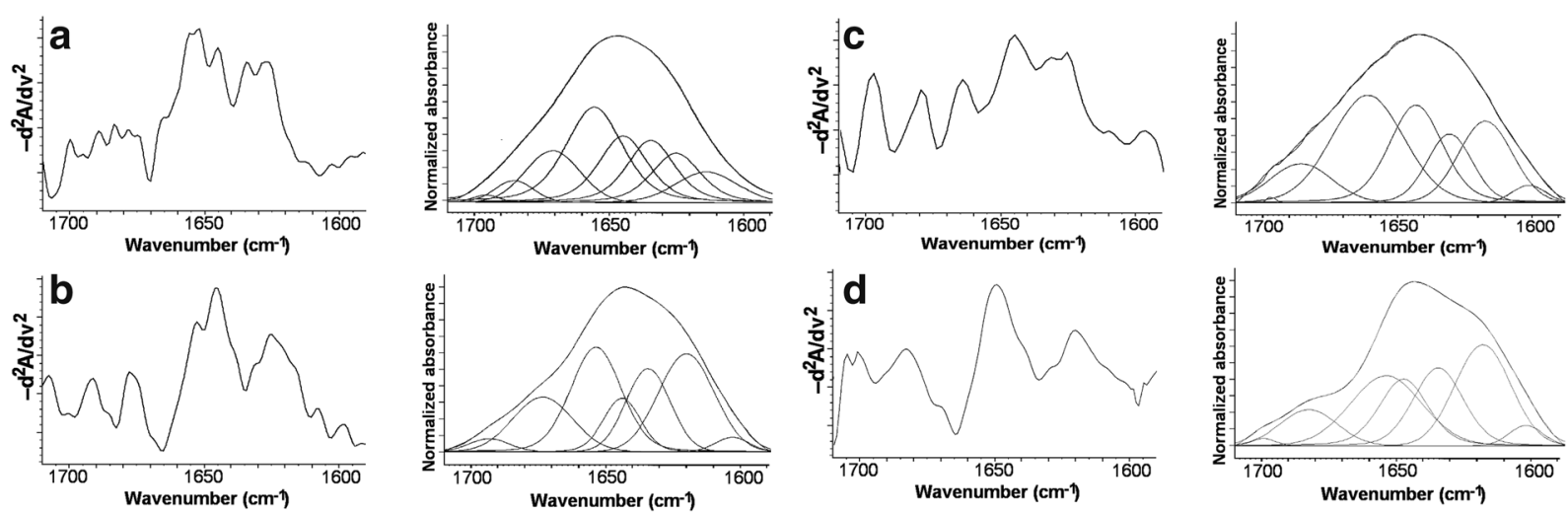

Fig. 5 The inverted second derivative FTIR spectra (left) and the curve-fitting analysis in the amide I region (right) of the free ChOX: a in the solid form, b in the buffer, c AuNP-ChOX

bionanocomplex in thin film form, and d AuNP-ChOX bionanocomplex suspended in the phosphate buffer

$10 \%$, the $17 \%$, the $23 \%$ for the suspended, the solid, and the immobilized ChOX form); however, the positions of the related peaks are consistent (the $1644 \mathrm{~cm}^{-1}$, the $1645 \mathrm{~cm}^{-1}$, and the $1644 \mathrm{~cm}^{-1}$, respectively).

The maintenance of the $\alpha$-helix structure can be related to the preservation of the catalytic activity of the enzyme (Delfino et al. 2013), which was confirmed by the biochemical analysis (Wojnarowska et al. 2015a). A phenomenon of increasing the amount of the $\alpha$-helix and decreasing of the $\beta$-sheet structure registered in the case of human flavine-containing monooxygenase (hFMO) enzyme under the interaction with the AuNP. The hFMO catalytic activity also was preserved (Castrignanò et al. 2012). However, Huang et al. notes that the interaction between the AuNP and the protein depends on the protein type and size and the nanoparticle size (Huang et al. 2013). Therefore, each case should be checked individually.

The study of the protein structure can be expanded by the amide II and the amide III band analysis. However, they are not as sensitive to the corresponding bonds as the previously described amide I. As it is reported by Barth (2007), the $\sim 7 \%$ of errors in the prediction of the protein structure can be even mineralized by the careful pretreatment of the spectra.

\section{Conclusion}

We have demonstrated that the FTIR-ATR technique is the effective method used to study the conformational changes of the ChOX enzyme caused by the interaction between the AuNP nanoparticle and the ChOX protein via MHDA linker in the prepared bionanocomplex. The conducted analysis gives the valuable information. The position of the amide I and the II bands does not change

Table 3 The assignment of the amide I lines position to the secondary structure for the ChOX

\begin{tabular}{|c|c|c|c|c|c|c|c|c|}
\hline \multirow[t]{2}{*}{ Structure } & \multicolumn{2}{|l|}{ ChOX in buffer } & \multicolumn{2}{|l|}{ ChOX solid } & \multicolumn{2}{|c|}{ ChOX-AuNP in buffer } & \multicolumn{2}{|c|}{ ChOX-AuNP solid } \\
\hline & Peak position $\left(\mathrm{cm}^{-1}\right)$ & Area $(\%)$ & $\begin{array}{l}\text { Peak position } \\
\left(\mathrm{cm}^{-1}\right)\end{array}$ & Area $(\%)$ & $\begin{array}{l}\text { Peak position } \\
\left(\mathrm{cm}^{-1}\right)\end{array}$ & Area $(\%)$ & $\begin{array}{l}\text { Peak position } \\
\left(\mathrm{cm}^{-1}\right)\end{array}$ & Area $(\%)$ \\
\hline$\beta$-sheet & 1693 & 2.5 & 1696 & 0.8 & 1699 & 0.8 & 1696 & 0.9 \\
\hline$\beta$-turn & - & - & 1685 & 3.7 & 1683 & 9.5 & 1685 & 9.8 \\
\hline$\beta$-turn & 1673 & 15.2 & 1671 & 12.2 & - & - & - & - \\
\hline$\alpha$-helix & 1654 & 26.9 & 1655 & 28.2 & 1655 & 24.0 & 1662 & 32.7 \\
\hline Random & 1644 & 9.8 & 1645 & 17.4 & 1649 & 16.9 & 1644 & 23.5 \\
\hline$\beta$-sheet & 1635 & 17.4 & 1634 & 15.9 & 1636 & 19.4 & 1632 & 13.1 \\
\hline$\beta$-sheet & 1621 & 25.7 & 1625 & 13.0 & 1620 & 26.2 & 1619 & 17.7 \\
\hline Side chain & 1604 & 2.4 & 1614 & 8.9 & 1604 & 3.1 & 1604 & 2.3 \\
\hline
\end{tabular}


Table 4 The amide I position and the secondary structure composition (\%) for the ChOX enzyme in different forms, according to the relative area of the component bands

\begin{tabular}{llccc}
\hline ChOX form & Amide I band position $\left(\mathrm{cm}^{-1}\right)$ & \multicolumn{2}{l}{ Secondary structure } & \\
\cline { 3 - 5 } & & $\beta$-sheet $(\%)$ & $\alpha$-helix $(\%)$ & Others $(\%)$ \\
\hline ChOX in buffer & 1640 & 45.7 & 26.9 & 27.4 \\
ChOX solid & 1645 & 29.4 & 28.2 & 42.4 \\
ChOX-AuNP in buffer & 1643 & 46,4 & 24,0 & 29,6 \\
ChOX-AuNP solid & 1642 & 31.8 & 32.7 & 35.5 \\
\hline
\end{tabular}

significantly- the shift of the maximum is about $2-$ $3 \mathrm{~cm}^{-1}$, which indicates only a slight change in the secondary structure of the protein after the immobilization process. Some number of the lines observed in the fingerprint region change their positions and their shapes, for example: the $v(\mathrm{C}-\mathrm{C})$, the $v(\mathrm{C}-\mathrm{O})$, and the $\mathrm{O}-\mathrm{H}$ out of plane bending vibrations. However, the line attributed to the P-O-C vibration at about the $990 \mathrm{~cm}^{-1}$ confirms the presence of the FAD cofactor in the ChOX, and it does not change its location much. This quite constant line allows to determine the presence of the FAD cofactor also in the other flavoproteins. The composition of the separate lines of the C-H band are strongly dependent on the environment conditions (because of the hydrogen bonds). Due to the use of the MHDA linker rich in the $\mathrm{C}-\mathrm{H}$ groups, the analysis of the $\mathrm{CH}$ bands of the enzyme after the immobilization is not possible because the linker has the significant contribution to this spectral region.

The secondary structure of the ChOX enzyme has been studied in detail. The domination of the $\beta$-sheet structure $(\sim 46 \%)$ was determined with a smaller contribution of the $\alpha$-helix structure $(\sim 27 \%)$ for $\mathrm{ChOX}$ suspended in the water solution. The similar results obtained for the immobilized enzyme in the same buffer medium ( $\sim 46 \%$ for $\beta$-sheet and $24 \%$ for $\alpha$-helix). For the solid form of the free and the immobilized ChOX, the contribution of the $\beta$-sheet decreased, while the content of $\alpha$-helix only slightly changed. It indicated the preservation of the protein catalytic activity after the immobilization, which was confirmed by the biochemical analysis.

From the methodological point of view, the obtained results indicate that the ATR approach is the very useful method for the study of the enzyme structure under the interaction of the protein with the nanoparticles. This fast and accurate method allows for the quick identification of the differences in the structure of the enzyme influenced by the local environments. This purpose becomes particularly important in the context of the bionanotechnology related to the coupling of the nanoparticles and the nanomaterials with the biological molecules (often the proteins) and for the fast control of the properties of the engineered bionanomaterials, as well as the presence of the potentially undesirable changes in their biological structures.

Funding information The authors received financial support through the Grant for Young Scientist, grant no. WMP/GMN-14/ 2017.

\section{Compliance with ethical standards}

Conflict of interest The authors declare that they have no conflict of interest.

Open Access This article is licensed under a Creative Commons Attribution 4.0 International License, which permits use, sharing, adaptation, distribution and reproduction in any medium or format, as long as you give appropriate credit to the original author(s) and the source, provide a link to the Creative Commons licence, and indicate if changes were made. The images or other third party material in this article are included in the article's Creative Commons licence, unless indicated otherwise in a credit line to the material. If material is not included in the article's Creative Commons licence and your intended use is not permitted by statutory regulation or exceeds the permitted use, you will need to obtain permission directly from the copyright holder. To view a copy of this licence, visit http://creativecommons.org/licenses/by/4.0/.

\section{References}

Alarcon EI, Bueno-Alejo CJ, Noel CW, Stamplecoskie KG, Pacioni NL, Poblete H, Scaiano JC (2013) Human serum 
albumin as protecting agent of silver nanoparticles: role of the protein conformation and amine groups in the nanoparticle stabilization. J Nanopart Res 15:1374

Amendola V, Pilot R, Frasconi M, Maragò OM, Iatì MA (2017) Surface plasmon resonance in gold nanoparticles: a review. J Phys Condens Matter 29(20):203002

Baker MJ, Trevisan J, Bassan P, Bhargava R, Butler HJ, Dorling KM, Fielden PR, Fogarty SW, Fullwood NJ, Heys KA, Hughes C, Lasch P, Martin-Hirsch PL, Obinaju B, Sockalingum GD, Sulé-Suso J, Strong RJ, Walsh MJ, Wood BR, Gardner P, Martin FL (2014) Using Fourier transform IR spectroscopy to analyze biological materials. Nat Protoc 9(8):1771-1791

Barnes L, Dereux A, Ebbesen TW (2003) Surface plasmon subwavelength optics. Nature. 424:824-830

Barth A (2000) The infrared absorption of amino acid side chains. Prog Biophys Mol Bio 74:141-173

Barth A (2007) Infrared spectroscopy of proteins. Biochim Biophys Acta 1767:1073-1101

Barth A, Zscherp CQ (2002) What vibrations tell us about proteins? Rev Biophys 35:369-430

Castrignanò S, Sadeghi SJ, Gilardi G (2012) Entrapment of human flavin-containing monooxygenase 3 in the presence of gold nanoparticles: TEM, FTIR and electrocatalysis. Biochim Biophys Acta 1820(12):2072-2078

Coates J (2000) Interpretation of infrared spectra, a practical approach. In: Meyers RA (ed) Encyclopedia of analytical chemistry. John Wiley \& Sons Ltd, Chichester, pp 1081510837

Delfino I, Portaccio M, Della Ventura B, Mita DG, Lepore M (2013) Enzyme distribution and secondary structure of solgel immobilized glucose oxidase by micro-attenuated total reflection FT-IR spectroscopy. Mater Sci Eng C Mater Biol Appl 33(1):304-310

Dembereldorja U, Ganbolda EO, Seoa JH, Leeb SY, Yangc SI, Joo SW (2012) Conformational changes of proteins adsorbed onto $\mathrm{ZnO}$ nanoparticle surfaces investigated by concentration-dependent infrared spectroscopy. Vib Spectrosc 59:23-28

El-Naggar NE-A, Soliman HM, El-Shweihy NM (2018) Extracellular cholesterol oxidase production by Streptomyces aegyptia, in vitro anticancer activities against rhabdomyosarcoma, breast cancer cell-lines and in vivo apoptosis. Sci Rep 8:2706

Gadda G, Wels G, Pollegioni L, Zucchelli S, Ambrosius D, Pilone MS, Ghisla S (1997) Characterization of cholesterol oxidase from Streptomyces hygroscopicus and Brevibacterium sterolicum. Eur J Biochem 250:369-376

Global Burden of Disease Collaborative Network. Global Burden of Disease Study 2016 (GBD 2016) Results. Seattle, United States: Institute for Health Metrics and Evaluation (IHME), 2017

Haes AJ, Van Duyne RP (2002) A nanoscale optical biosensor: sensitivity and selectivity of an approach based on the localized surface plasmon resonance spectroscopy of triangular silver nanoparticles. J Am Chem Soc 124:10596-10604

Hassanzadeh J, Khataee A (2018) Ultrasensitive chemiluminescent biosensor for the detection of cholesterol based on synergetic peroxidase-like activity of MoS2 and graphene quantum dots. Talanta. 178:992-1000
Herizchi R, Abbasi E, Milani M, Akbarzadeh A (2016) Current methods for synthesis of gold nanoparticles. Artif Cells Nanomed Biotechnol 44:596-602

Huang R, Carney RP, Stellacci F, Lau BL (2013) Proteinnanoparticle interactions: the effects of surface compositional and structural heterogeneity are scale dependent. Nanoscale. 5(15):6928-6935

Ivanov AI, Zhbankov RG, Korolenko EA, Korolik EV, Meleshchenko LA, Marchewka M, Ratajczak H (1994) Infrared and Raman spectroscopic studies of the structure of human serum albumin under various ligand loads. J Appl Spectrosc 60:305-309

Kong J, Yu S (2007) Fourier transform infrared spectroscopic analysis of protein secondary structures. Acta Biochim Biophys Sin 39:549-559

Kumar S, Yadav I, Kumar Aswal V, Kohlbrecher J (2018) Structure and interaction of nanoparticle-protein complexes. Langmuir. 34(20):5679-5695

Kumari L, Kanwar SS (2012) Cholesterol oxidase and its applications advances in microbiology. Adv Microbiol 2:49-65

Lowry OH, Rosebrough NJ, Farr AL, Randall RJ (1951) Protein measurements with the Folin phenol reagent. J Biol Chem 193:267-275

Lv C, Tang Y, Wang L, Wenming JL, Chen Y, Yang S, Wang W (2002) Bioconversion of yolk cholesterol by extra-cellular cholesterol oxidase from Brevibacterium sp. Food Chem 77: 457-463

Machan S, Weerapreeyakul N, Barusrux S, Thumanu K, Tanthanuch W (2012) FTIR microspectroscopy discriminates anticancer action on human leukemic cells by extracts of Pinus kesiya; Cratoxylum formosum ssp pruniflorum and melphalan. Talanta 93:371-382

MacLachlan J, Wotherspoon ATL, Ansell RO, Brooks CJW (2000) Cholesterol oxidase: sources, physical properties and analytical applications. J Steroid Biochem Mol Biol 72:169-195

Malek K (2016) Spektroskopia oscylacyjna. PWN Warszawa 121144

Malek K, Wood BR, Bambery K (2014) FTIR imaging of tissues: techniques and methods of analysis. In: Baranska M (ed) Optical spectroscopy and computational methods in biology and medicine, vol 14. Springer, pp 419-473

Mobili P, Londero A, Maria TMR, Eusebio MES, De Antoni GL, Fausto R, Gomez-Zavaglia A (2009) Characterization of Slayer proteins of Lactobacillus by FTIR spectroscopy and differential scanning calorimetry. Vib Spectrosc 50:68-77

Mokwebo KV, Oluwafemi OS, Arotiba OA (2018) An electrochemical cholesterol biosensor based on a CdTe/CdSe/ZnSe quantum dots-poly (propylene imine) dendrimer nanocomposite immobilisation layer. Sensors 18:3368

Neelama, Chhillar AK, Rana JS (2019) Enzyme nanoparticles and their biosensing applications: a review. Anal Biochem 581: 113345

Nie S, Emory SR (1997) Probing single molecules and single nanoparticles by surface-enhanced Raman scattering. Science. 275:1102-1106

Nirala NR, Saxena PS, Srivastava A (2018) Colorimetric detection of cholesterol based on enzyme modified gold nanoparticles. Spectrochim Acta A Mol Biomol Spectrosc 190:506-512

Paluszkiewicz C, Piergies N, Chaniecki P, Rękas M, Miszczyk J, Kwiatek WM (2017) Differentiation of protein secondary 
structure in clear and opaque human lenses: AFM - IR studies. J Pharm Biomed Anal 139:125-132

Pollegioni L, Piubelli L, Molla G (2009) Cholesterol oxidase: biotechnological applications. FEBS J 276:6857-6870

Ravindran A, Singh A, Raichur AM, Chandrasekaran N, Mukherjee A (2010) Studies on interaction of colloidal Ag nanoparticles with bovine serum albumin (BSA). Colloid Surf B 76:32-37

Rios-Corripio AMA, Garcia-Perez BE, Jaramillo-Flores ME, Gayou VL, Rojas-Lopez M (2013) UV-visible intensity ratio (aggregates/single particles) as a measure to obtain stability of gold nanoparticles conjugated with protein. J Nanopart Res 15:1624

Saxena U, Goswami P (2010) Silk mat as bio-matrix for the immobilization of cholesterol oxidase. Appl Biochem Biotechnol 162(4):1122-1131

Saxena U, Goswami P (2012) Electrical and optical properties of gold nanoparticles: applications in gold nanoparticlescholesterol oxidase integrated systems for cholesterol sensing. J Nanopart Res 14:813

Saxena U, Chakraborty M, Goswami P (2011a) Covalent immobilization of cholesterol oxidase on self-assembled gold nanoparticles for highly sensitive amperometric detection of cholesterol in real samples. Biosens Bioelectron 26:30373043

Saxena U, Das M, Ahmad S, Barbora L, Borthakur M, Verma A, Bora U, Goswami P (2011b) Multiwalled carbon nanotubebased bi-enzyme electrode for total cholesterol estimation in human serum. J Exp Nanosci 6:84-95

Sharma D, LeeJ SJ, Shin H (2017) Development of a sensitive electrochemical enzymatic reaction-based cholesterol biosensor using nano-sized carbon interdigitated electrodes decorated with gold nanoparticles. Sensors. 17(9):2128

Spalding K, Bonnier F, Brunob C, Blasco H, Board R, Benz-de Bretagne I, Byrne HJ, Butler HJ, Chourpa I, Radhakrishnan P, Baker MJ (2018) Enabling quantification of protein concentration in human serum biopsies using attenuated total reflectance - Fourier transform infrared (ATR-FTIR) spectroscopy. Vib Spectrosc 99:50-58

Spexard M, Immeln D, Thöing C, Kottke T (2011) Infrared spectrum and absorption coefficient of the cofactor flavin in water. Vib Spectrosc 57(2):282-287

Stuart BH (2004) Infrared spectroscopy. Fundamentals and application. John Wiley \& Sons. Chichester. 137-165

Stuart DA, Yuen JM, Shah N, Lyandres O, Yonzon CR, Glucksberg MR, Walsh JT, Van Duyne RP (2006) In vivo glucose measurement by surface-enhanced Raman spectroscopy. Anal Chem 78:7211-7215

Tabassum S, Al-Asbahy WM, Afzal M, Arjmand F (2012) Synthesis, characterization and interaction studies of copper based drug with human serum albumin (HSA): spectroscopic and molecular docking investigations. J Photochem Photobiol B Biol 114:132-139

Talat M, Singh AK, Srivastava ON (2011) Optimization of process variables by central composite design for the immobilization of urease enzyme on functionalized gold nanoparticles for various applications. Bioprocess Biosyst Eng 34:647-657

Turkevich J, Stevenson PC, Hillier J (1951) A study of the nucleation and growth processes in the synthesis of colloidal gold. Discuss Faraday Soc 11:55-76

Vrielink A (2010) Cholesterol oxidase: structure and function. In: Harris JR (ed) Cholesterol binding and cholesterol transport proteins, vol 51. Springer, pp 137-158

Vrielink A, Ghisla S (2009) Cholesterol oxidase: biochemistry and structural features. FEBS J 276:6826-6843

Walsh G (2002) Proteins: biochemistry and biotechnology. Wiley, Chichester, pp 18-23

Wang L, Wang W (2007) Coenzyme precursor-assisted expression of a cholesterol oxidase from Brevibacterium sp. in Escherichia coli. Biotechnol Lett 29:761-766

Wojnarowska R, Polit J, Broda D, Gonchar M, Sheregii EM (2015a) Surface enhanced Raman scattering as a probe of the cholesterol oxidase enzyme. Appl Phys Lett 106:103701103704

Wojnarowska R, Polit J, Broda D, Gonchar M, Sheregii EM (2015b) Gold nanoparticles like a matrix for covalent immobilization of cholesterol oxidase - application for biosensing. Arch Metall Mater 60(3):2289-2296

Wolpert M, Hellwig P (2006) Infrared spectra and molar absorption coefficients of the 20 alpha amino acids in aqueous solutions in the spectral range from 1800 to $500 \mathrm{~cm}^{-1}$. Spectrochim Acta A Mol Biomol Spectrosc 64(4):987-1001

Zhang H, Song D, Gao S, Zhang J, Zhang H, Sun Y (2013) Novel SPR biosensors based on metal nanoparticles decorated with graphene for immunoassay. Sensor Actuat B-Chem 188: 548-554

Publisher's note Springer Nature remains neutral with regard to jurisdictional claims in published maps and institutional affiliations. 